\title{
Teaching NeuroImages: Imaging phenotype of myoclonic epilepsy with ragged-red fibers
}

Rahul Nikam, MBBS, Ashrith R. Kandula, and Kathleen Schenker, MD

Neurology ${ }^{\circledR}$ 2020;94:e2187-e2188. doi:10.1212/WNL.0000000000009438

Figure Imaging and magnetic resonance spectroscopy

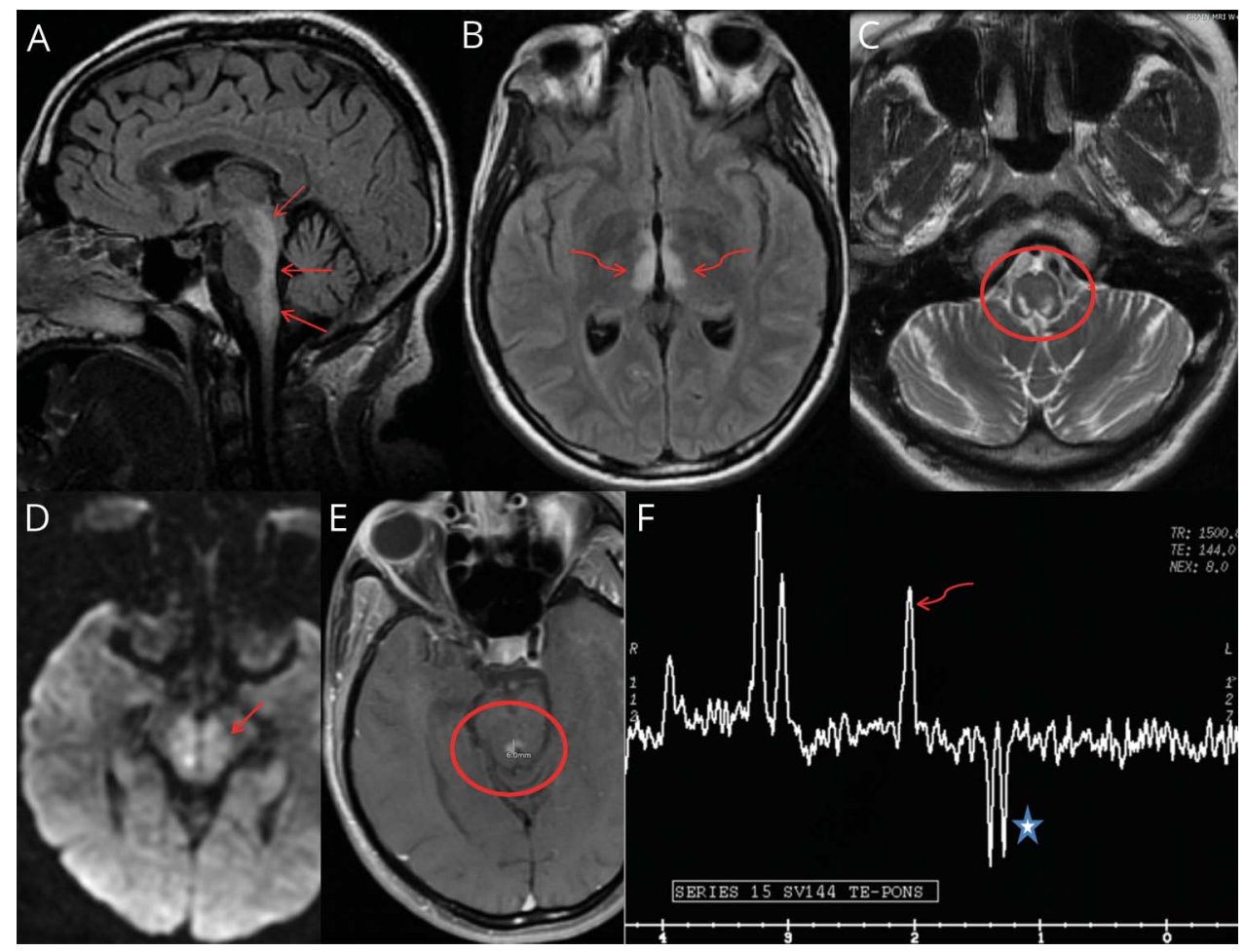

Sagittal fluid-attenuated inversion recovery (FLAIR) image (A) shows abnormal hyperintense signal in the mesencephalon, posterior aspect of pons, and medulla oblongata (arrows). Axial FLAIR (B) shows hyperintensity extending superiorly to the medial aspect of thalami (curved arrows). Axial T2 (C) depicts extension of signal abnormality inferiorly to posterolateral aspect of medulla oblongata (circle). Axial diffusion-weighted imaging sequence (D) demonstrates mild restricted diffusion in the tegmentum of midbrain (arrow). Axial T1 postcontrast image (E) depicts enhancement in the periaqueductal gray matter (circle). Spectroscopy long echo time (144) (F) shows elevated lactate at $1.3 \mathrm{ppm}$ (star) and decrease in $\mathrm{N}$-acetylaspartate at $2.0 \mathrm{ppm}$ (curved arrow).

A 17-year-old girl presented with subacute decline in ambulation, ataxia, generalized weakness, dysphagia, and asymmetric hearing loss. MRI findings include abnormal signal in medial thalami, mesencephalon, posterior pons, and medulla oblongata (figure). Magnetic resonance spectroscopy showed elevated lactate and decrease in $\mathrm{N}$-acetylaspartate (figure, F). DNA isolated from muscle biopsy showed A8344G mutation of mitochondrial DNA (tRNA [Lys] gene), associated with $80 \%$ of patients with myoclonic epilepsy with ragged-red fibers (MERRF). MERRF is a rare mitochondrial disorder with variable onset and clinical presentation. Neuroradiologic findings of MERRF are reported rarely, with brainstem and cerebellar degeneration being the main feature of MERRF. ${ }^{1}$

\section{Correspondence}

Dr. Nikam

rahulnikam@hotmail.com

\section{MORE ONLINE}

\section{$\rightarrow$ Teaching slides}

links.lww.com/WNL/

B85 


\section{Study funding}

No target funding reported.

\section{Disclosure}

The authors report no relevant disclosures. Go to Neurology. org/ $\mathrm{N}$ for full disclosures.

\section{Appendix Authors}

\begin{tabular}{lll}
\hline Name & Location & Contribution \\
\hline Rahul & Nemours A.I. DuPont Hospital & Drafting, critical revision \\
Nikam, & for Children, Wilmington, DE & for intellectual content \\
MBBS & & \\
\hline
\end{tabular}

\section{Appendix (continued)}

\begin{tabular}{lll}
\hline Name & Location & Contribution \\
\hline $\begin{array}{l}\text { Ashrith R. } \\
\text { Kandula }\end{array}$ & $\begin{array}{l}\text { Nemours A.I. DuPont Hospital } \\
\text { for Children, Wilmington, DE }\end{array}$ & $\begin{array}{l}\text { Concept and design, } \\
\text { revision }\end{array}$ \\
\hline $\begin{array}{l}\text { Kathleen } \\
\begin{array}{l}\text { Schenker, } \\
\text { MD }\end{array}\end{array}$ & $\begin{array}{l}\text { Nemours A.I. DuPont Hospital } \\
\text { for Children, Wilmington, DE }\end{array}$ & $\begin{array}{l}\text { Concept and design, } \\
\text { supervision }\end{array}$ \\
\hline
\end{tabular}

\section{Reference}

1. Asahina M, Hattori T. Clinical and brain MR imaging features focusing on the brain stem and cerebellum in patients with myoclonic epilepsy with ragged-red fibers due to mitochondrial A8344G mutation. AJNR Am J Neuroradiol 2008;29: 392-395. 


\section{Neurology}

\section{Teaching NeuroImages: Imaging phenotype of myoclonic epilepsy with ragged-red fibers}

Rahul Nikam, Ashrith R. Kandula and Kathleen Schenker

Neurology 2020;94;e2187-e2188 Published Online before print April 23, 2020

DOI 10.1212/WNL.0000000000009438

This information is current as of April 23, 2020

\section{Updated Information \&} Services

References

Subspecialty Collections

Permissions \& Licensing

Reprints including high resolution figures, can be found at: http://n.neurology.org/content/94/20/e2187.full

This article cites 1 articles, 1 of which you can access for free at: http://n.neurology.org/content/94/20/e2187.full\#ref-list-1

This article, along with others on similar topics, appears in the following collection(s):

\section{Mitochondrial disorders}

http://n.neurology.org/cgi/collection/mitochondrial_disorders MRI

http://n.neurology.org/cgi/collection/mri

MRS

http://n.neurology.org/cgi/collection/mrs

Information about reproducing this article in parts (figures,tables) or in its entirety can be found online at:

http://www.neurology.org/about/about_the_journal\#permissions

Information about ordering reprints can be found online:

http://n.neurology.org/subscribers/advertise

Neurology ${ }^{\circledR}$ is the official journal of the American Academy of Neurology. Published continuously since 1951, it is now a weekly with 48 issues per year. Copyright () 2020 American Academy of Neurology. All rights reserved. Print ISSN: 0028-3878. Online ISSN: 1526-632X.

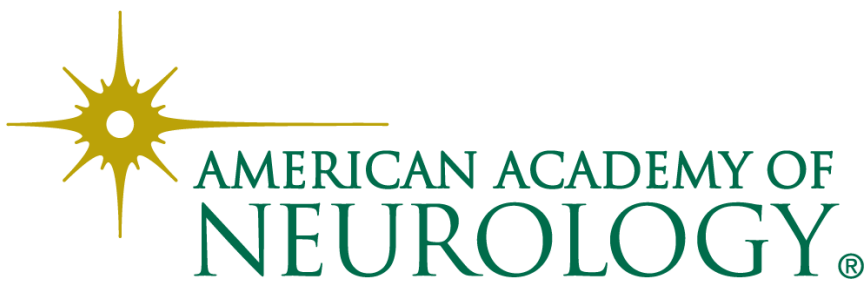

